\title{
Kandungan gizi dan Organoleptik Sie Reuboh dengan Penambahan Cuka Aren (Arenga pinnata) dan Daun Jeruk Purut (Citrus hystrix) pada Konsentrasi yang Berbeda
}

\author{
Nutrition Content and Organoleptic of Sie reuboh with Palm vinegar (Arenga pinnata) and Kaffir Lime \\ Liaves (Citrus hystrix) in Different Concentration. \\ Masyitah $^{1)}$, I. I. Arief ${ }^{2)}$, T.Suryati') \\ ${ }^{1)}$ Mahasiswa Sekolah Pascasarjana Ilmu Produksi dan Teknologi Peternakan, IPB \\ ${ }^{2}$ Departemen Produksi dan Teknologi Peternakan, Fakultas Peternakan, IPB
}

\begin{abstract}
This research aimed to study and evaluate the nutritional composition of sie reuboh treated with different concentrations of palm vinegar (Arenga pinnata) and kaffir lime leaves (Citrus hystrix) addition. The four treatments for sie reuboh were $\mathrm{P0}(0 \mathrm{~mL}$ palm vinegar and 0 kaffir lime leaves), P1 (100 mL palm vinegar and $10 \mathrm{kaffir}$ lime leaves, $P 2(100 \mathrm{~mL}$ palm vinegar and $10 \mathrm{kaffir}$ lime leaves). The parametes are nutrition content (water content, ash content, fat content, protein content and carbohydrates content) and organoleptic (hedonic qualiy test and hedonic test). The result showed that different concentrations of palm vinegar and kaffir lime leaves addition significantly affected $(\mathbf{p}<0.05)$ ash content and carbohydrates content of sie reuboh. Ash content in this study ranged from $3.11 \%$ to $2.43 \%$ and carbohydrates content ranged $3.89 \%$ to $5.59 \%$. The result of organoleptic showed that were significantly affected $(\mathbf{p}<\mathbf{0 . 0 5})$ on hedonic quality test (flavor of palm vinegar, flavour kaffir lime leaves and taste). The value of palm vinegar flavor has 3.17 to 3.83 , the value of kaffir lime leaves has 3.00 to 3.57 and the taste value has 3.30 to 3.77. Different level of palm vinegar and kaffir lime leaves not affected at moisture content, protein content, fat content, hedonic quality (color and tenderness) and hedonic (color, flavor, taste, tenderness and overall appearance).
\end{abstract}

Key words: Sie reuboh, Nutrition content, Organoleptic, palm vinegar, lime lives

\section{PENDAHULUAN}

Daging adalah salah satu komoditi peternakan yang diharapkan untuk memenuhi kebutuhan protein yang bermutu tinggi dan mampu memenuhi zat gizi yang dibutuhkan oleh tubuh karena memiliki kandungan asam amino esensial yang lengkap. Menurut Devatkal et al. (2012) menyatakan daging merupakan jaringan otot hewan disembelih terdiri dari air, protein, lipid, mineral dan sebagian kecil dari karbohidrat. Daging segar dan produk daging rentan terhadap penurunan kualitas karena kaya akan komposisi gizi. Produk pangan dibeli konsumen jika kualitasnya memuaskan. Penentuan mutu bahan pangan biasanya didasarkan pada beberapa faktor diantaranya penampakan, aroma dan bau serta tekstur produk. Mutu sensori ditentukan oleh keadaan fisik dan kimiawi produk (Estiasih dan Ahmadi 2009). Daging dalam bentuk segar tidak dapat bertahan lama sehingga perlu dilakukan pengawetan berupa pengolahan lebih lanjut untuk tujuan meningkatkan nilai gizi, memperpanjang masa simpan, meningkatkan nilai ekonomis dan selera konsumen. Peningkatan akan kebutuhan gizi dari daging dapat dilakukan melalui diversifikasi pengolahan daging salah satunya adalah produk sie reuboh.

Sie reuboh adalah produk olahan daging yang berasal dari Aceh yang diolah dengan menambahkan bumbu-bumbu, cuka aren dan lemak sampai daging menjadi empuk. Kandungan gizi sie reuboh dengan perlakuan pemanasan berulang terdiri dari kadar air 54,54\% - 58,77 $\%$, kadar protein 82,38 \%- 62,60\%, kadar lemak 19,47\% $24,95 \%$ dan daya cerna protein 79,83 \% - 87,42 \% (Suhairi 2007). Cuka aren sebagai salah satu bumbu sie reuboh yang memberikan rasa asam yang khas pada produk ini juga merupakan sebagai pengawet alami karena kandungan asam asetat. Cuka aren merupakan hasil fermentasi nira aren. Menurut Plessi (2003) menyatakan cuka terdiri dari proses fermentasi dua tahap, yaitu fermentasi alkohol dan fermentasi asam asetat. Tahap pertama adalah fermentasi alkohol, gula difermentasi dikonversi menjadi etanol dan $\mathrm{CO}_{2}$ dalam kondisi anaerob oleh ragi spesies Saccharomyces. Tahap kedua adalah fermentasi asam asetat, alkohol dibentuk pada tahap pertama diubah menjadi asam asetat dan air dalam kondisi aerobik oleh bakteri asam asetat termasuk Acetobacter aceti, A. pastorianus dan A. hansenii . Ferdiaz (1983) menyatakan asam asetat menyebabkan perubahan pH, kadar air serta nilai susut masak. Penambahan asam berarti menurunkan $\mathrm{pH}$ yang disertai dengan naiknya konsentrasi ion hidrogen $\left(\mathrm{H}^{+}\right)$dan $\mathrm{pH}$ rendah lebih besar penghambatannya pada pertumbuhan mikroba (Cahyadi 
2009). Asam asetat berfungsi membantu mempertahankan dan mendorong kemantapan produk pangan termasuk warna, rasa, aroma serta tekstur, sehingga kualitas dapat dipertahankan (Tranggono 1990). Penambahan daun jeruk purut menjadi salah satu bumbu pada produk sie reuboh sebagai peningkat cita rasa dan aroma. Selain itu, daun jeruk purut merupakan sumber antioksidan yang baik pada produk yang mengandung lemak. Cahyadi (2009) menyatakan antioksidan merupakan senyawa yang dapat memperlambat oksidasi. Meliputi bahan, antara lain lemak hewani, produk pangan dengan kadar lemak tinggi, produk pangan berkadar lemak rendah, produk daging, produk ikan dan produk lainnya. Di Indonesia daun jeruk purut digunakan sebagai bumbu masak. (Rahmi 2013). Daun jeruk perut (Citrus hystrix) memiliki senyawa kimia yang merupakan metabolit skunder adalah minyak atsiri, flavonoid, saponin, dan terpen (Adrianto et al. 2014). Untuk ekstrak kulit dan daun Citrus hystrix memiliki aktivitas antioksidan alami yang baik. Flavonoid adalah senyawa fenolik penting yang memiliki aktivitas antioksidan kuat (Licina et al. 2013). Penelitian ini dilakukan untuk mengetahui kandungan gizi dan organoleptik produk sie reuboh dengan penambahan cuka aren dan daun jeruk purut dengan konsentrasi yang berbeda.

\section{MATERI DAN METODA}

\section{Pembuatan Sie reuboh}

Daging yang digunakan untuk pembuatan sampel sie reuboh adalah daging sapi bagian knucle (paha atas) sebanyak $4 \mathrm{~kg}$. Daging yang diperoleh dari RPH Elders, IPB. Komposisi bahan pembuatan sie reuboh untuk $1 \mathrm{~kg}$ daging yaitu jahe $20 \mathrm{~g}$, garam $15 \mathrm{~g}$, kunyit segar 20, lengkuas 20 g, bawang putih $15 \mathrm{~g}$, cabe merah segar $25 \mathrm{~g}$, cabe merah bubuk $10 \mathrm{~g}$, cabe rawit $10 \mathrm{~g}$, air $300 \mathrm{~mL}$, cuka aren $(0 \mathrm{~mL}$, $100 \mathrm{~mL}, 120 \mathrm{~mL}$ dan $140 \mathrm{~mL})$ dan daun jeruk purut $(0 \mathrm{~g}, 10$ g, $20 \mathrm{~g}$ dan $30 \mathrm{~g})$.

Prosedur pembuatan sie reuboh mengacu kepada Suhairi (2007) yaitu daging sapi dibersihkan dari lemak dan dipotong dadu dengan berat 40-60 g kemudian dicuci sebanyak 2 kali serta ditiriskan selama 5-10 menit. Bumbubumbu digiling halus. Bumbu halus, daging dan air di masukkan dalam wadah kuali tanah kemudian dilakukan pemasakan selama \pm 15 menit kemudian ditambahkan cuka dan dilakukan pemasakan selama \pm 45 menit. Setelah \pm 45 menit, dimasukkan daun jeruk purut yang diremas dan disobek acak kemudian dilanjutkan pemasakan sampai air mengering. Sie reuboh siap dianalisis kandungan nutrisi dan organoleptik.

\section{Kandungan gizi Sie Reuboh}

Untuk mengetahui kandungan gizi sie reuboh dengan penambahan cuka aren dan daun jeruk purut dengan kosentrasi berbeda, maka dilakukan analisis proximat dengan standar analisis AOAC (2005).

Kadar air. Sampel $1 \mathrm{~g}$ ditimbang dalam cawan. Sampel dimasukkan kedalam pada suhu $105^{\circ} \mathrm{C}$ selama 8 jam, lalu timbang. Kadar air dihitung dengan rumus :

Kadar Air $(\%)=\frac{\text { Bobot segar }- \text { Bobot kering }}{\text { Bobot segar }} \times 100 \%$
Kadar abu. Sampel 1 g ditempatkan dalam cawan porselain lalu dibakar sampai tidak berasap, kemudian diabukan dalam tanur suhu $600^{\circ} \mathrm{C}$ selama 6 jam. Lalu ditimbang. Kadar abu dihitung dengan rumus:

$$
\text { Kadar Abu }(\%)=\frac{\text { Bobot abu }}{\text { Bobot sampel }} \times 100 \%
$$

Kadar protein. Sampel 0,25 g dimasukkan dalam labu kjeldahl $100 \mathrm{~mL}$ dan tambahkan selenium $0,25 \mathrm{~g}$ dan 2 $\mathrm{mL} \mathrm{H}_{2} \mathrm{SO}_{4}$ pekat dan lakukan destruksi (pemanasan dalam keadaan mendidih) selama 1 jam sampai larutan jernih.

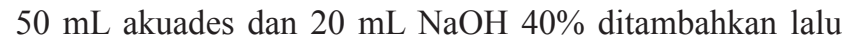
destilasi. Hasil destilasi dicampuran $10 \mathrm{~mL} \mathrm{H}_{3} \mathrm{BO}_{3} 2 \%$ dan 2 tetes indicator brom cresol green-methyl red berwarna merah muda. Setelah volume hasil penampungan (destilat) menjadi $10 \mathrm{~mL}$ dan berwarna hijau kebiruan. Hasil destilasi dititrasi dengan HCL 0,1 N sampai berwarna merah muda. Perlakuan yang sama dilakukan juga terhadap blanko. Kadar protein diperoleh dengan mengalikan kadar Nitrogen dengan factor perkalian untuk berbagi bahan pangan berkisar 5,186,38 . Dengan metode ini diperoeh kadar nitrogen total yang dihitung dengan rumus :

$$
\text { Nitrogen }(\%)=\left[(\mathrm{S}-\mathrm{B}) \times \mathrm{NHCl} \times \frac{14}{w} \times 1000\right] 100 \%
$$

Keterangan : $\mathrm{S}=$ Volume titran sampel $(\mathrm{mL}), \mathrm{B}=$ Volume titran blanco $(\mathrm{mL})$ dan $\mathrm{w}=$ Bobot sampel kering $(\mathrm{mg})$.

Analisis kadar lemak. Sampel $2 \mathrm{~g}$ disebar diatas kapas yang beralas kertas saring dan digulung membentuk thimble lalu dimasukkan kedalam lab soxhlet. Kemudian diekstraksi selama 6 jam dengan pelarut lemak berupa heksan sebanyak $150 \mathrm{~mL}$. Lemak yang terekstrak kemudian dikeringkan dalam oven pada suhu $100^{\circ} \mathrm{C}$ selama 1 jam. Kadar lemak ditentukan dengan rumus sebagai berikut:

$$
\text { Kadar lemak }(\%)=\frac{\text { Bobot lemak terekstrak }}{\text { Bobot sampel }} \times 100 \%
$$

Kadar Karbohidrat. Kadar karbohidrat total ditentukan dengan metode carbohidrat by difference yaitu :

$$
100 \%-(\text { kadar protein + lemak + air + abu). }
$$

\section{Kualitas Organoleptik Sie reuboh}

Untuk mengetahui tingkat penerimaan panelis terhadap penambahan cuka aren dan daun jeruk purut dengan kosentrasi berbeda pada produk sie reuboh, maka dilakukan evaluasi sensori dengan metode skoring 1-5 dengan 30 panelis terlatih pada uji mutu hedonik dan 30 panelis tidak terlatih pada uji hedonik. Panelis memberikan penilaian dengan petunjuk yang diberikan (Setyaningsih et al. 2010). Analisis pengujian organoleptik yaitu uji mutu hedonik meliputi warna, aroma cuka aren, aroma daun jeruk, rasa dan keempukan serta uji hedonik meliputi warna, rasa, aroma, keempukan dan penampakan.

\section{Analisis Data}

Metode penelitian yang digunakan adalah metode percobaan dengan desain Rancangan Acak Kelompok (RAK) dengan 4 perlakuan dan 3 ulangan. Sebagai perlakuan adalah cuka aren dan daun jeruk purut disusun sebagai berikut :

$\mathrm{P} 0=0 \quad \mathrm{~mL}$ cuka aren $+0 \mathrm{~g}$ daun jeruk purut $\mathrm{P} 1=100 \mathrm{~mL}$ cuka aren $+10 \mathrm{~g}$ daun jeruk purut 
$\mathrm{P} 2=120 \mathrm{~mL}$ cuka aren $+20 \mathrm{~g}$ daun jeruk purut

$\mathrm{P} 3=140 \mathrm{~mL}$ cuka aren $+30 \mathrm{~g}$ daun jeruk purut

Parameter yang diamati pada penelitian ini adalah kandungan gizi meliputi kadar air, kadar lemak, kadar protein, kadar abu dan kadar karbohidrat. Analisis pengujian organoleptik yaitu uji mutu hedonik meliputi : warna, aroma cuka aren, aroma daun jeruk, rasa dan keempukan serta uji hedonik meliputi : warna, rasa, aroma, keempukan dan penampakan.

Pengaruh penambahan cuka aren dan daun jeruk purut dengan konsentrasi berbeda pada sie reuboh dianalisis menggunakan sidik ragam (Anova) dilakukan dengan menggunakan softwear Statistical Analysis System 's Procedures (SAS) bila terdapat data yang berpengaruh nyata maka akan diuji menggunakan uji Duncan Multiple Range Test (DRMT) pada taraf kepercayaan $95 \%(\alpha=0,05)$. Organoleptik dianalisis dengan metode aplikasi Statistix non parametrik Kruskal-Walli dan apabila terdapat data berpengaruh nyata maka akan diuji dengan menggunakan All-Pairwise Comparisons Test.

\section{HASIL DAN PEMBAHASAN}

\section{Kandungan Nutrisi Sie Reuboh}

Penambahan cuka aren dan daun jeruk purut dengan kosentrasi yang berbeda belum diketahui kandungan gizi pada produk sie reuboh, kandungan gizi ini dapat diketahui dengan cara analisis proksimat. Hasil analisis sidik ragam pada penelitian ini menunjukkan bahwa dengan penambahan cuka aren dan daun jeruk purut dengan konsentrasi yang berbeda berpengaruh nyata $(\mathrm{p}<0,05)$ terhadap kadar abu dan kadar karbohidrat. Kandungan gizi sie reuboh dengan penambahan cuka aren dan daun jeruk purut pada kosentrasi berbeda dapat dilihat pada Tabel 1 .

\section{Kadar abu}

Nilai kadar abu sie reuboh pada penelitian ini berkisar 3,11 \% - 2,94\%. Nilai kadar abu menunjukkan penurunan seiring meningkatnya cuka aren yang ditambahkan. Hal ini diakibatkan semakin tinggi kosentrasi cuka aren yang ditambahkan dapat mengekstraksi protein pada daging sehingga semakin banyak mineral yang keluar bersama air bebas yang keluar dari dalam daging. Ferdiaz (1983) menyatakan sifat asam pada cuka dapat mengekstrak protein (Pelepasan protein oleh daging akibat melemahnya ikatan protein miofibril dalam daging) sehingga semakin banyak asam cuka nira aren, protein terekstrak lebih banyak akibat dari melemahnya ikatan protein miofibril pada daging mengakibatkan banyak air bebas yang keluar dari dalam daging. Menurut Andarwulan et al. (2011) pengaruh pengolahan pada bahan dapat mempengaruhi ketersediaan mineral bagi tubuh. Penggunaan air pada proses pencucian, perendaman dan perebusan dapat mengurangi ketersediaan mineral karena mineral akan larut oleh air yang digunakan.

Abu merupakan zat organik sisa hasil pembakaran suatu bahan organik. Kandungan abu dan komposisisnya tergantung dari jenis bahan pangan. Sekitar $96 \%$ bahan pangan terdiri dari bahan organik dan air. Sisanya terdiri dari unsur-unsur mineral yag dikenal dengan unsur-unsur anorganik (abu). Komponen-komponen bahan organik terbakar, tetapi komponen anorganiknya tidak karena itulah disebut abu (Winarno 2008).

\section{Kadar karbohidrat}

Nilai kadar karbohidrat sie reuboh pada penelitian ini berkisar 3,89\% - 5,56\%. Setiap perlakuan cenderung menunjukkan peningkatan kadar karbohidrat. Cuka aren yang digunakan pada penelitian ini masih mengandung total gula $0,60 \% \mathrm{~b} / \mathrm{b}$ hal ini yang mengakibatkan kenaikan kadar karbohidrat pada produk sie reuboh. Glukosa merupakan komponen dari karbohidrat yang penting dan makan untuk pertumbuhan mikroba dalam proses fermentasi secara alami dan rasanya tidak manis lagi. Dalam keadaan segar cuka aren merupakan air nira yang rasanya manis yang kadar gulanya cukup tinggi. Sie reuboh penelitian ini menunjukkan kadar air yang semakin menurun mengakibatkan komponen karbohidrat, protein dan mineral menjadi meningkat. Menurut Muchtadi et al. (2010) menyatakan dengan berkurangnya kadar air suatu bahan pangan akan meningkatkan kosentrasi senyawa senyawa seperti karbohidrat, protein dan mineral yang lebih tinggi, akan tetapi vitamin-vitamin dan zat warna pada umumnya menjadi rusak atau berkurang.

\section{Kadar air}

Nilai kadar air sie reuboh pada penelitian ini berkisar 58,70 \% - 58,11\%. Sifat asam pada cuka aren yang dapat mengekstrak protein daging akibat melemahnya ikatan protein miofibril sehingga mengakibatkan banyak air bebas yang keluar dari dalam daging. Kadar air produk daging proses tergantung pada produk dan regulasi. Produk daging proses biasanya mengandung cairan sekitar $45 \%$ - $60 \%$ kecuali produk daging kering. Daging akan lebih

Tabel 1 Kandungan gizi sie reuboh dengan penambahan cuka aren dan daun jeruk purut pada konsentrasi berbeda

\begin{tabular}{|c|c|c|c|c|}
\hline \multirow[t]{2}{*}{ Peubah } & \multicolumn{4}{|c|}{ Perlakuan } \\
\hline & $\mathrm{P} 0$ & $\mathrm{P} 1$ & $\mathrm{P} 2$ & P3 \\
\hline & - & \% b/b --------- & -------- & --------------- \\
\hline Kadar air & $58,7 \pm 1,14$ & $58,48 \pm 1,78$ & $58,4 \pm 0,85$ & $58,11 \pm 1,144$ \\
\hline Kadar abu & $3,11 \pm 0,36 \mathrm{a}$ & $2,94 \pm 0,15 \mathrm{a}$ & $2,70 \pm 0,12 \mathrm{ab}$ & $2,43 \pm 0,18 b$ \\
\hline Kadar lemak & $5,79 \pm 1,44$ & $4,89 \pm 2,72$ & $4,22 \pm 1,28$ & $4,50 \pm 1,38$ \\
\hline Kadar Pprotein & $28,5 \pm 2,81$ & $28,84 \pm 2,02$ & $29,06 \pm 1,42$ & $29,05 \pm 1,16$ \\
\hline Kadar karbohidrat & $3,89 \pm 0,41 b$ & $4,83 \pm 0,44 b$ & $5,60 \pm 0,62 \mathrm{a}$ & $5,56 \pm 1,12 \mathrm{ab}$ \\
\hline
\end{tabular}

Keterangan : Angka yang diikuti huruf yang berbeda pada baris yang sama menunjukkan berpengaruh nyata $(\mathrm{p}<0,05): \mathrm{P} 0(0 \mathrm{~mL}$ cuka aren $+0 \mathrm{~g}$ daun jeruk purut), P1 (100 mL cuka aren +10 gr daun jeruk purut), P2 (120 mL cuka aren +20 gr daun jeruk purut), P3 (140 mL cuka aren+30 gr daun jeruk purut). 
cepat rusak bila kadar airnya tinggi, sehingga daging yang berkualitas tinggi, kadar airnya harus dalam batas yang normal . Hasil penelitian Hasil penelitian Tarigan (2004) daging sapi asam yang diberi perlakuan cuka nira aren 40 $\mathrm{mL}$ memiliki kadar air terendah yaitu 45,81\% dan yang tertinggi menggunakan kadar cuka nira aren $20 \mathrm{~mL}$ yaitu $50,72 \%$.

\section{Kadar Lemak}

Nilai rata-rata kadar lemak sie reuboh pada penelitian ini berkisar 5,79 \% - 4,50\%. Perlakuan P3 menunjukkan peningkatan lemak akan tetapi tidak berbeda secara signifikan, hal ini diduga pada saat dilakukan pembersihan lemak yang melekat pada daging tidak memperoleh hasil yang sama dan daging diperoleh pada hari yang berbeda untuk setiap kelompok ulangan. Asam asetat (asam organik) dari cuka aren yang menyebabkan terjadinya hidrolisa asam terhadap lemak produk sie reuboh. Hal tersebut distimulir oleh hidrolisis lemak yang dipercepat larutan cuka aren yang bersifat asam. Salah satu faktor kerusakan lemak dipercepat oleh asam (Winarno 1992). Adanya lemak dalam jumlah berlebihan dalam bahan pangan kadang-kadang kurang dikehendaki. Tingginya kadar lemak suatu bahan pangan berpotensi pada penurunan mutu, menyebabkan mikroorganisme mudah berkembang biak. Apabila disimpan dalam jangka waktu tertentu resiko ketengikan akibat mikroorganisme juga meningkat sehingga daya simpannya menurun. Menurut Cakrawati dan Mustika (2011) proses pemanasan dapat menurunkan kadar lemak bahan pangan. Kadungan lemak daging sapi yang tidak dipanaskan (dimasak) rata-rata mencapai 17,2 \%, sedang jika dimasak dengan suhu $60^{\circ} \mathrm{C}$, lemak akan turun menjadi 11,2-13,2\%. Adanya lemak dalam jumlah berlebihan dalam bahan pangan kadang-kadang kurang dikehendaki.

\section{Kadar protein}

Nilai kadar protein sie reuboh pada penelitian ini berkisar 28,50 \% - 29,05 \%. Perlakuan P3 menunjukkan penurunan protein akan tetapi tidak berbeda secara signifikan Kandungan asam lemah tidak banyak menghidrolisis protein yang terkandung dalam daging sie reuboh. Asam asetat adalah merupakan asam organik yang aman untuk makanan, asam asetat banyak digunakan sebagai pengkhelat bahan makanan karena asam asetat mempunyai 1 elektron bebas pada gugus karboksilatnya, sehingga asam asetat mampu mengikat logam. Asam asetat merupakan asam lemah, elektrolit lemah, derajat disosiasinya rendah yaitu 0,013 (Winarno 2004). Cuka aren dapat menurunkan pH serta mempertahankan kadar protein karena asam dapat menekan reaksi pencoklatan yang dapat merusak protein. Peningkatan kadar asam dalam jaringan daging sie reuboh akan menekan reaksi pencoklatan non-enzimatik yang mengakibatkan kerusakan protein karena asam amino sekundernya berikatan dengan gula pereduksi. Kadar air yang menurun diikuti dengan peningkatnya kadar protein sie reuboh. Hasil penelitian Prayitno et al. (2012) melaporkan kadar protein dendeng kelinci mengalami peningkatan diduga karena adanya proses pengeringan membuat kadar air dendeng berkurang, sehingga persentase kadar protein dendeng menjadi tinggi.

\section{Organoleptik Sie Reuboh}

Karakteristik sensori sie reuboh merupakan parameter dari produk daging olahan yang diuji secara subyetif oleh panelis yang terdiri dari uji mutu hedonik meliputi warna, aroma cuka aren, aroma daun jeruk purut, rasa dan keempukan sedangkan uji hedonik meliputi warna, rasa, aroma, keempukan dan penampakan. Kualitas organoleptik sie reuboh dengan penambahan cuka aren dan daun jeruk purut pada kosentrasi berbeda dapat dilihat pada Tabel 2.

\section{Mutu Hedonik}

Hasil analisis sidik ragam pada penelitian ini menunjukkan bahwa dengan penambahan cuka aren dan daun jeruk purut dengan kosentrasi yang berbeda pada mutu

Tabel 2 Organoleptik sie reuboh dengan penambahan cuka aren dan daun jeruk purut pada kosentrasi berbeda

\begin{tabular}{lccccc}
\hline Perlakuan & \multicolumn{5}{c}{ a. Uji mutu hedonik } \\
\cline { 2 - 6 } & Warna & Aroma cuka aren & Aroma daun jeruk & Rasa & Keempukan \\
\cline { 2 - 6 } & $2,33 \pm 1,30$ & $3,83 \pm 0,79 \mathrm{a}$ & $2,47 \pm 1,01 \mathrm{~b}$ & $2,80 \pm 0,81 \mathrm{~b}$ & $3,50 \pm 0,90$ \\
P0 & $3,03 \pm 1,25$ & $3,07 \pm 0,94 \mathrm{~b}$ & $3,00 \pm 0,87 \mathrm{ab}$ & $3,77 \pm 0,94 \mathrm{a}$ & $3,30 \pm 0,92$ \\
P1 & $2,60 \pm 1,28$ & $3,43 \pm 0,94 \mathrm{ab}$ & $3,33 \pm 0,92 \mathrm{a}$ & $3,30 \pm 0,80 \mathrm{ab}$ & $3,47 \pm 0,97$ \\
P2 & $2,77 \pm 1,25$ & $3,17 \pm 1,02 \mathrm{ab}$ & $3,57 \pm 1,01 \mathrm{a}$ & $3,77 \pm 0,73 \mathrm{a}$ & $3,70 \pm 0,95$ \\
\hline P3 & $2,68 \pm 0,29$ & $3,38 \pm 0,34$ & $3,09 \pm 0,48$ & $3,41 \pm 0,46$ & $3,49 \pm 0,16$ \\
\hline Rata-rata & & b. Uji hedonik & & Keempukan \\
\hline & $3,00 \pm 1,05$ & $2,83 \pm 0,81$ & $3,33 \pm 0,83$ & $3,10 \pm 0,84$ & $2,40 \pm 0,80$ \\
\hline P0 & $3,30 \pm 0,87$ & $2,86 \pm 0,96$ & $2,70 \pm 0,88$ & $3,03 \pm 0,90$ & $3,03 \pm 0,76$ \\
P1 & $3,30 \pm 0,95$ & $3,46 \pm 0,95$ & $3,00 \pm 0,78$ & $3,20 \pm 0,96$ & $3,33 \pm 0,84$ \\
P2 & $3,23 \pm 0,99$ & $3,06 \pm 1,07$ & $2,76 \pm 0,69$ & $3,36 \pm 1,00$ & $3,26 \pm 0,78$ \\
P3 & $3,21 \pm 0,14$ & $3,05 \pm 0,29$ & $3,02 \pm 0,33$ & $3,17 \pm 0,14$ & $3,07 \pm 0,44$ \\
\hline Rata-rata & & & Rasa & \\
\hline
\end{tabular}

Keterangan : Angka yang diikuti huruf yang berbeda pada kolom yang sama menunjukkan berpengaruh nyata $(\mathrm{P}<0,05)$ dengan uji lanjut All-Pairwise Comparisons Test : P0 ( $0 \mathrm{~mL}$ cuka aren $+0 \mathrm{~g}$ daun jeruk pururt), $\mathrm{P} 1$ (100 $\mathrm{mL}$ cuka aren $+10 \mathrm{~g}$ daun jeruk purut), P2 (120 mL cuka aren+20 g daun jeruk purut), P3 (140 $\mathrm{mL}$ cuka aren $+30 \mathrm{~g}$ daun jeruk purut). 
hedonik berpengaruh nyata $(\mathrm{p}<0,05)$ terhadap aroma cuka aren, aroma daun jeruk purut dan rasa (Tabel 2a).

\section{Aroma cuka aren}

Penilaian tertinggi sie reuboh terhadap aroma cuka aren didapat pada perlakuan P0 ( 0 cuka aren $+0 \mathrm{~g}$ daun jeruk purut) yaitu 3,82 dengan panelis cenderung memilih tidak bau cuka. Mengindikasikan perlakuan P0 tidak adanya tercium aroma asam karena tidak adanya penambahan cuka aren. Sebelum terjadinya fermentasi, nira aren berbau harum, tidak berwarna dan memiliki rasa yang manis (Muchtadi et al. 2010). Nira aren digunakan sebagai bahan baku pembuatan cuka aren tampak sedikit lebih kental namun setelah mengalami proses fermentasi menjadi cuka, bentuknya menjadi encer dan beraroma sangat asam (Baharudin et al. 2009).

\section{Aroma daun jeruk purut}

Penilaian tertinggi sie reuboh terhadap aroma daun jeruk purut pada perlakuan P3 (140 mL cuka aren $+30 \mathrm{~g}$ daun jeruk purut) yaitu 3,47 dengan panelis cenderung memilih bau daun jeruk purut. Hal ini mengindikasikan, semakin tinggi kosentrasi daun jeruk purut menunjukkan aroma daun jeruk semakin kuat. Komponen terbesar dalam minyak atsiri daun jeruk purut adalah sitronellal. Menurut Kataren (1995) sitronella yang terdiri dari campuran terpenoid yang memberikan aroma khusus pada minyak daun jeruk purut. Sitronela termasuk senyawa minyak atsiri yang berwarna kuning dan mudah menguap pada suhu kamar. Senyawa berbau menjadi lebih stabil, sehingga konsentrasi tinggi senyawa ini mencapai reseptor di hidung (Engelen et al. 2003).

Rasa

Pada penilaian rasa sie reuboh nilai tertinggi didapat pada perlakuan P3 (140 mL cuka aren+30 g daun jeruk purut) yaitu 3,77 dengan panelis cenderung memilih asam. Mengindikasikan semakin tinggi kosentrasi penambahan cuka aren menghasilkan produk bercita rasa asam. Dalam fermentasi nira aren terbentuk asam asetat, asam asetat didalam cuka memberikan rasa asam dan dapat menurunkan $\mathrm{pH}$ pada sie reuboh yang berfungsi sebagai pengawet. Menurut Estiasih dan Ahmadi (2009) peranan utama asam dalam pengolahan adalah memberikan rasa asam. Keasaman sedang dapat menurunkan $\mathrm{pH}$ dibawah 4,5. Penambahan asam menurunkan kondisi termal dan menghambat pertumbuhan mikroba berbahaya. Evaluasi bau dan rasa masih (terutama) tergantung pada taste panelis. Keragaman antara individu dalam respon intensitas dan kualitas terhadap stimulus tertentu dan pada individu tertentu (Lawrie 2003). Cuka aren juga berfungsi mempertahankan kualitas produk pangan termasuk warna, rasa dan aroma serta tekstur.

\section{Warna}

Hasil penilaian tertinggi terhadap warna sie reuboh pada perlakuan P1 (100 mL cuka aren $+10 \mathrm{~g}$ daun jeruk pururt) yaitu 3,03, panelis cenderung memilih agak kekuningan sampai kuning. Penambahan cuka aren dan daun jeruk purut dapat mempertahankan kualitas wana pada sie reuboh. Menurut Bintoro (2008) menyatakan warna pada daging dan olahan dapat diperoleh dari pengaruh cara pengolahan dan bahan yang ditambahkan. Menurut
Murdijati dan Gardjito (2013) cuka juga dipakai untuk mencegah berubahnya warna buah dan sayuran karena oksidasi. Asam bersifat sinergis terhadap antioksidan dalam mencegah ketengikan dan browning pada bahan makanan yang mengandung karbohidrat, protein minyak atau lemak (Tranggono 1990).

\section{Keempukan}

Berdasarkan hasil analisis keempukan sie reuboh menunjukkan P3 (140 mL cuka aren+30 g daun jeruk purut) yaitu 3,62, panelis cenderung memilih empuk. Menururt Lawrie (2003) peningkataan keempukan merupakan refleksi dari kadar air yang lebih besar dan kapasitas memegang air dari protein urat daging yang lebih besar pula. Keempukan merupakan parameter yang bersifat subjektif karena berhubungan dengan tingkat penetrasi gigi dan daging yang menimbulkan sensasi pada saat pengunyahan. Standar keempukan setiap individu berbeda (Suryati et al. 2007).

\section{Uji Hedonik}

Uji hedonik banyak digunakan untuk mengevaluasi penerimaan produk secara keseluruhan dan itu dinyatakan sebagai tingkat penerimaan konsumen. Pada uji hedonik menunjukkan kosentrasi penambahan cuka aren dan daun jeruk purut yang tidak berpengaruh nyata $(p>0,05)$ terhadap warna, aroma, rasa, keempukan dan penampakan (Tabel 2b).

\section{Warna}

Warna merupakan salah satu sifat dari sensori produk olahan daging yang utama. Berdasarkan penilaian warna sie reuboh menunjukkan P1 (100 mL cuka aren +10 $\mathrm{g}$ daun jeruk purut) dan P2 (120 mL cuka aren $+20 \mathrm{~g}$ daun jeruk purut), memiliki nilai tertinggi yaitu 3,30. Panelis cenderung memilih antara netral sampai suka. Hal ini dikarenakan penambahan cuka aren dan daun jeruk purut dapat menjaga kestabilan warna dari sie reuboh. Menurut Murdijati dan Gardjito (2013) cuka dipakai untuk memberi rasa asam pada masakan bisa mengawetkan sayuran atau buah karena sifatnya yang asam, cuka juga dipakai untuk mencegah berubahnya warna buah dan sayuran karena oksidasi. Antioksidan yang terkandung didalam daun jeruk purut efektif dalam mempertahankan warna pada produk sie reuboh. Antioksidan fenolik hadir dalam rempah-rempah dan herbal yang digunakan sebagai aditif makanan dapat mencegah oksidasi lipid dan kerusakan warna, rasa dan kualitas gizi produk makanan (Kozłowska et al.2014).

\section{Aroma}

Aroma yang dihasilkan sie reuboh dengan nilai rata-rata tertinggi pada $\mathrm{P} 2(120 \mathrm{~mL}$ cuka aren $+20 \mathrm{~g}$ daun jeruk purut) yaitu 3,46. Panelis cenderung memilih netral. Asam cuka nira aren mengandung $1 \%$ asam asetat yang telah dianalisa aman dipakai sebagai bahan tambahan pangan serta dapat mempertahankan kualitas produk termasuk warna, rasa, aroma dan tekstur. Citrus hystrix adalah Salah satu spesies dari suku rustaceae atau jeruk purut. Di Indonesia daun jeruk purut digunakan sebagai bumbu masak (Rahmi 2013). Daun jeruk purut memiliki aroma yang khas dan dapat meningkatkan cita rasa pada masakan.

\section{Rasa}

Rasa sie reuboh dengan rata-rata tertinggi berada pada P0 (0 mL cuka aren $+0 \mathrm{~g}$ daun jeruk purut) yaitu 
3,33. Panelis cenderung memilih antara netral sampai suka. Menurut Konczak et al. (2010) bahan alami dan rempahrempah digunakan untuk meningkatkan rasa, warna dan aroma makanan. Selain meningkatkan rasa, bumbu dan rempah-rempah juga dikenal karena pengawet antioksidan dan peran antimikroba. Formulasi bumbu dan proses yang berbeda menghasilkan produk dengan cita rasa yang berbeda Keempukan

Keempukan yang dihasilkan sie reuboh dalam penelitian ini menunjukkan nilai rata-rata tertinggi pada P3 (140 mL cuka aren $+30 \mathrm{~g}$ daun jeruk purut) yaitu 3,36 . Panelis cenderung memilih netral sampai suka. Impresi secara umum keempukan termasuk tektur melibatkan 3 aspek. Pertama, mudah atau tidaknya dari gigi berpenetrasi awal kedalam gigi. Kedua, mudah atau tidaknya daging tersebut dapat dipecah menjadi bagian-bagian yang lebih kecil. Ketiga, jumlah residu yang tertinggal setelah dikunyah (Lawrie 2003).

\section{Penampakan}

Pengamatan keseluruhan sie reuboh berdasarkan penilaian panelis menunjukkan nilai tertinggi pada $\mathrm{P} 2$ (120 mL cuka aren $+20 \mathrm{~g}$ daun jeruk purut) yaitu 3,33. Panelis cenderung memilih antara netral sampai suka. Pada umumnya konsumen yang mengonsumsi sesuatu produk baru berdasarkan karakteristik produk secara keseluruhan bukan dilihat dari satu atribut saja. Tingkat kesukaan pada perlakuan lain pun disukai oleh panelis dan menunjukkan tidak berbeda signifikan. Menurut Soeparno (2009) bahwa nilai daging didasarkan atas tingkat akseptabilitas konsumen, kepuasan yang berasal dari konsumen daging tergantung pada respon fisiologis dan sensori diantara individu.

\section{KESIMPULAN}

Produk sie reuboh dengan penambahan cuka aren dan daun jeruk purut dengan konsentrasi yang berbeda mempengaruhi kandungan gizi meliputi kadar abu dan kadar karbohidrat dan hasil organoleptik mempengaruhi mutu hedonik meliputi aroma cuka aren, aroma daun jeruk purut dan rasa. Dengan mengetahui kandungan gizi dan daya terima sensori produk ini sebagai salah satu diversifikasi produk olahan daging yaitu sie reuboh, maka dapat dijadikan sebagai alat peningkatan kebutuhan nutrisi bagi masyarakat indonesia.

\section{DAFTAR PUSTAKA}

[AOAC] Association Official Analitycal Chemistry. 2005. Official Method of Analysis. Ed ke-18. Maryland (US): AOAC Inc.

Andarwulan NF, Kusnandar, Herawati D. 2011. Analisis Pangan. Dian Rakyat. Jakarta. Halaman 328.

Adrianto H, Yotopranoto S, Hamidah. 2014. Efektivitas Ekstrak Daun Jeruk Purut (Citrus hystrix), Jeruk Limau ((Citrus amblycarpa), dan Jeruk Bali (Citrus maxima) Terhadap Larva Aedes aegypti. Jurnal Aspirator. 6 (1) ; 1-6.

Baharuddin, Syahidah, Yatni N. 2009. Penentuan Mutu Nira aren (Arenga pinnata) berdasarkan SNI 01-4371-
1996. Jurnal Perennial. 5(1) ; 31-35.

Cahyadi W. 2009. Bahan Tambahan Pangan. Edisi ke dua. Penerbit Bumi Aksara. Jakarta

Cakrawati D, Mustika NH. 2012. Bahan Pangan, Gizi dan Kesehatan. Cetakan kesatu. Penerbit Afabeta. Bandung.

Deman JM. 1997. Kimia Makanan. Bandung. Penerbit ITB.

Devatkal SK, Naveena BM. 2010. Effect of salt, kinnow and pomegranate fruitby-product powders on color and oxidative stability of raw ground goatmeatduring refrigerated storage. Meat Sci. 85 (2); 306-311.

Engelen L, Engelen RA, Wijk JF, Prinz AM, Janseen H, Weenen F, Bosman. 2003. The effect of oral and product temperature on the perception of flavor and texture attributes of semi-solids. Appetite. $41 ; 273-$ 281.

Estiasih T, Ahmadi KGS. 2014. Teknologi Pengolahan Pangan. Cetakan ketiga. Penerbit PT. Bumi Aksara. Jakarta.

Fardiaz S. 1983. Analisis Mikrobiologi Pangan. Pusat Antar Universitas Pangan dan Gizi. Institut Pertanian Bogor, Bogor.

Ketaren S. 1995. Pengantar Teknologi Minyak dan Lemak Pangan. Universitas (UI) Press. Jakarta

Konczak I, Zabaras D, Dunstan M, Aguas P.2010. Antioxidant capacity and phenolic compounds in commercially grown native Australian herbs and spices. Food Chemistry 122 (1): 260-266.

Kozlowska M, Żbikowska A, Gruczynska E, Żontała E, Półtorak A. 2014. Effects of spice extracts on lipid fraction oxidative stability of cookies investigated by DSC. Journal of Thermal Analysis and Calorimetry 118 (2014): 1697-1705.

Lawrie RA. 2003. Ilmu Daging. Edisi Kelima. Diterjemahkan oleh Aminuddin Parakkasi. Penerbit Universitas Indonesia, Press. Jakarta.

Licina BZ, Stefanovic OD, Vasic SM, Radojevic ID, Dekic MS, Comic LR. 2013. Biological activities of the extracts from wild growing Origanum vulgareL. Jurnal Food Control. 33; 498-504.

Muchtadi TR, Sugiono, Ayustaningwarno F. 2010. Teknologi Proses Pengolahan Pangan. Alfabeta. Bandung.

Mudijati, Gardito. 2013. Bumbu, Penyedap dan Penyerta Masakan Indonesia. P.T.Gramedia Pustaka Utama, Anggota IKAPI. Jakarta 2011: 50-54.

Plessi M. 2003. Vinegar. In B. Caballero(Ed.), Encyclopedia of food sciences and nutrition (2nd ed.). (pp. 59966004). Oxford: Academic Press.

Prayitno AH, Saputra DPA, Kurniati A, Widyastuti H, Utami RR, Soeparno, Rusman. 2012. Pengaruh Metode Pembuatan dan Pengeringan Yang Berbeda Terhadap Karakteristik Fisik, Kimia dan Sensoris Dendeng Daging Kelinci. Buletin Peternakan 36 (2) : 113-121.

Rahmi U, Yunazar M, Adlis S. 2013. Profil Fitokimia Metabolit Sekunder dan Uji Aktivitas Antioksidan Tanaman Jeruk Purut (Citrus histrix DC) dan Jeruk Bali (Citrus maxima (Burm.f.) Merr). Jurnal Kimia Unand. ISSN No. 2303-3401, hal : 109-114. 
Setyaningsih D, Apriyantono A, Sari MP. 2010. Sensory analysis for food and agro. Bogor: IPB Press.

Soeparno. 2009. Ilmu dan Teknologi Daging. Universitas Gadjah Mada Press, Yogyakarta.

Suhairi L. 2007. Pemanasan Berulang terhadap Kandungan Gizi "Sie reuboh" Makanan Tradisional Aceh. Tesis. Fakultas Gizi Masyarakat dan Sumber Daya Keluarga. Institut Pertanian Bogor. IPB.

Suryati T, Arief II, Polii BN. 2008. Korelasi dan Kategori keempukan Daging Berdasarkan Hasil Pengujian menggunakan Alat dan Panelis. Animal production 10: 188-193. ISSN 1411-2027.

Tarigan A. 2004. Pengaruh Penggunaan Asam Cuka Nira Aren terhadap Daging Sapi Asam. Seminar Nasional Teknologi Peternakan dan Veteriner.

Tranggono. 1990. Bahan Tambahan Pangan. Universitas Gajah Mada Press, Yogyakarta.

Winarno FG. 1992. Kimia Pangan dan Gizi. PT. Gramedia Pustaka Utama. Jakarta

Winarno FG. 2004. Kimia Pangan dan Gizi. Cetakan Keempat. Penerbit PT Gramedia Pustaka Utama. Jakarta.

Winarno FG. 2008. Kimia Pangan dan Gizi. PT. Gramedia Pustaka. 